\title{
A Comparison of Land Use Classifications in Urbanized Areas in Selected European Countries
}

\begin{abstract}
The real estate cadastre is the primary source of information on land use. It records information related to the division of land into types based on the actual way of land use or development. The distinguished types of land use depend on many geographical factors, as well as historical and economic conditions.

The study presents a comparison of the detail of land use classification registered in the real estate cadastre in areas functionally related to the urban areas of 9 European countries: Austria, Bulgaria, the Czech Republic, Estonia, Spain, Lithuania, Luxembourg, Germany and Poland.

The research concerned the determination of the degree to which the classification of land use in urbanized areas is detailed, whether the studied European countries are characterized by the same number of distinguished classes of objects at different levels of detail, and what percentage are the distinguished classes of land use objects in urbanized areas in relation to all of the distinguished classes of objects land use at different levels of detail of classification. The study used legal acts regulating land use issues which have been made available in national languages by government institutions.
\end{abstract}

Keywords: land use, land cover, cadastre, urban areas, land use / land cover registration

Received: 21 October 2020; accepted: 16 November 2020

(C) 2021 Author. This is an open access publication, which can be used, distributed and reproduced in any medium according to the Creative Commons CC-BY 4.0 License.

1 Military University of Technology, Faculty of Civil Engineering and Geodesy, Warsaw, Poland, email: olga.matuk@wat.edu.pl, ORCID ID: https://orcid.org/0000-0003-1251-2671 


\section{Introduction}

The primary source of information on land use is the real estate cadastre.

Land information plays a major role in the economic development of every country, and it is necessary to create economic policy at many administrative levels, from local to national and even global.

Recent decades have been characterized by a rapid evolution of the land use information system, initiated by the need to ensure greater effectiveness of land management activities. Institutions collecting cadastral information promote the pursuit of mutual knowledge and comparative analysis of cadastral systems, including knowledge on land use [1,2]. The scope of information on land use in various countries depends on legal regulations and their detail [3].

The article presents the functioning of land use classifications in selected European countries, distinguishing the number of detail levels and the number of land use object classes at the distinguished levels of detail. The study concerned the thematic scope of information on land use in nine European countries, namely: Austria, Bulgaria, the Czech Republic, Estonia, Spain, Lithuania, Luxembourg, Germany and Poland.

The article deals with research issues concerning the detail of land use classification functionally related to urbanized areas, distinguishing the number of levels of detail of the classification. In addition, it was examined whether the analyzed countries are characterized by the same number of distinguished classes of land use objects at individual levels of detail and what percentage are the distinguished classes of land use objects related to urbanized areas in relation to all distinguished classes of land use objects at individual levels of detail of the classification.

\section{Data and Methods}

The study on the scope of the number of levels of classification detail, the number of distinguished classes of facilities in urban areas and the percentage share of the distinguished classes of facilities in urban areas in relation to all distinguished classes of facilities was carried out for nine European countries. The existing classifications are based on various source data [4] and classification criteria, which affect both the separated land and their definitions [5]. For the most part, the division of land is hierarchical [6] and at the highest level there are urbanized, agricultural, forests and water areas [7].

The cadastre in Poland gathers a wealth of relevant information. Taking into account the number of detail classification levels, the registration regulations allow for the occurrence of approx. 250 variants of object classes. The number of classification detail levels and individual object classes at each detail level has a direct impact on the accuracy of land use classification [8]. 
Achieving the intended research goals was based on a comparative analysis of materials and legal acts regarding the conduct of cadastral systems made available by cadastral governmental institutions. Research materials [9-18] were shared by nine European countries. They are characterized by a different structure and detail, with some of them only available in their national languages.

The study of materials with a different structure and detail requires the adoption of certain action schemes, i.e. finding objects that are definitional and functionally similar to one another. The study of materials allowed us to distinguish the number of levels of detail and classes of land use objects.

For the purpose of assessing the classification detail, the fundamental criterion was the number of distinguished levels of detail. To this end, three levels of classification detail have been distinguished. Those are:

- level 1 with a very range of detail - 4 or more levels of land use detail;

- level 2 with an average level of detail - from 2 to 3 levels of detail in land use;

- level 3 with a narrow level of detail - 1 level of detail in land use.

The analysis of materials consisted in indicating the number of classes of objects thematically related to each other.

For the purposes of research, it was assumed that object classes not related to urban areas will not be taken into account in determining the number of object classes at particular levels of detail.

Using the statistical method, the percentage share of classes of objects related functionally to urbanized areas was calculated in relation to all classes of land use objects distinguished at particular levels of classification detail.

\section{Research and Research Results}

The study showed that the highest number of land use classification levels associated with urbanized areas is in Lithuania, Germany and Poland (3 levels each). The smallest one is in Bulgaria (level 1). A similar number of classification levels occur in Austria, the Czech Republic, Estonia, Spain and Luxembourg (2 levels each) (Tab. 1).

The examination of the scope of the classification's detail showed that:

- 1 country is characterized by a narrow level of detail (Bulgaria);

- 8 countries are characterized by a medium level of detail (Austria, the Czech Republic, Estonia, Spain, Lithuania, Luxemburg, Germany and Poland).

None of the analyzed countries has a wide range of detail in the classification.

The examination of the materials showed that the distinguished levels of detail of the classification contain classes of objects not related to urbanized areas. 
For the purposes of the study, the assumption adopted applied:

1. There are 8 registered classes at level 1 in Austria. 5 class out of 8 is not associated with urbanized areas. Therefore, 3 classes of land use were adopted for the analysis. There are 23 registered classes at level 2. 11 class out of 23 is not associated with urbanized areas. Therefore, 12 classes of land use were adopted for the analysis.

2. There are 7 registered classes at level 1 in Bulgaria. 3 class out of 7 is not associated with urbanized areas. Therefore, 4 classes of land use were adopted for the analysis.

3. There are 10 registered classes at level 1 in the Czech Republic. 7 class out of 10 is not associated with urbanized areas. Therefore, 3 classes of land use were adopted. There are 29 registered classes at level 2. 10 class out of 29 is not associated with urbanized areas. Therefore, 19 classes of land use were adopted for the analysis.

4. There are 13 registered classes at level 1 in Estonia. 2 class out of 13 is not associated with urbanized areas. Therefore, 11 classes of land use were adopted for the analysis.

5. There are 2 registered classes at level 1 in Spain. 1 class out of 2 is not associated with urbanized areas. Therefore, 1 class of land use were adopted for the analysis.

6. There are 5 registered classes at level 1 in Lithuania. 1 class out of 5 is not associated with urbanized areas. Therefore, 4 classes of land use were adopted for the analysis. There are 6 registered classes at level 2 . 2 class out of 6 is not associated with urbanized areas. Therefore, 4 classes of land use were adopted for the analysis. There are 7 registered classes at level 3 . 3 class out of 7 is not associated with urbanized areas. Therefore, 4 classes of land use were adopted for the analysis.

7. There are 9 registered classes at level 1 in Luxemburg. 3 class out of 9 is not associated with urbanized areas. Therefore, 6 classes of land use were adopted for the analysis. There are 49 registered classes at level 2. 20 class out of 49 is not associated with urbanized areas. Therefore, 29 classes of land use were adopted for the analysis.

8. There are 7 registered classes at level 1 in Germany. 2 class out of 7 is not associated with urbanized areas. Therefore, 5 classes of land use were adopted for the analysis. There are 42 registered classes at level 2. 17 class out of 42 is not associated with urbanized areas. Therefore, 25 classes of land use were adopted for the analysis. There are 41 registered classes at level 3. 6 class out of 41 is not associated with urbanized areas. Therefore, 35 classes of land use were adopted for the analysis.

9. There are 6 registered classes at level 1 in Poland. 3 class out of 6 is not associated with urbanized areas. Therefore, 3 classes of land use were adopted for the analysis. There are 14 registered classes at level 2. 7 class out of 14 
is not associated with urbanized areas. Therefore, 7 classes of land use were adopted for the analysis. There are 12 registered classes at level 3. 8 class out of 12 is not associated with urbanized areas. Therefore, 4 classes of land use were adopted for the analysis.

Table 1. The number of classification levels and the number of classes at each level of detail

\begin{tabular}{||c|c|c|c|c|c|c|c|c||}
\hline $\begin{array}{c}\text { Ord. } \\
\text { no. }\end{array}$ & Country & $\begin{array}{c}\text { Number } \\
\text { of clas- } \\
\text { sifica- } \\
\text { tion } \\
\text { levels }\end{array}$ & $\begin{array}{c}\text { Number } \\
\text { of classes } \\
\text { at the } 1^{\text {st }} \\
\text { detail } \\
\text { level }\end{array}$ & $\begin{array}{c}\text { Number } \\
\text { of classes } \\
\text { at the 2 } \\
\text { detail } \\
\text { level }\end{array}$ & $\begin{array}{c}\text { Number } \\
\text { of classes } \\
\text { at the } 3^{\text {rd }} \\
\text { detail } \\
\text { level }\end{array}$ & $\begin{array}{c}\text { Number } \\
\text { of classes } \\
\text { at the } 4^{\text {th }} \\
\text { detail } \\
\text { level }\end{array}$ & $\begin{array}{c}\text { Number } \\
\text { of classes } \\
\text { at the } 5^{\text {th }} \\
\text { detail } \\
\text { level }\end{array}$ & $\begin{array}{c}\text { Number } \\
\text { of classes } \\
\text { at the } 6^{\text {th }} \\
\text { detail } \\
\text { level }\end{array}$ \\
\hline \hline 1 & Austria & 2 & 3 & 12 & 0 & 0 & 0 & 0 \\
\hline 2 & Bulgaria & 1 & 4 & 0 & 0 & 0 & 0 & 0 \\
\hline 3 & the Czech Republic & 2 & 3 & 19 & 0 & 0 & 0 & 0 \\
\hline 4 & Estonia & 2 & 11 & 2 & 0 & 0 & 0 & 0 \\
\hline 5 & Spain & 2 & 1 & 3 & 0 & 0 & 0 & 0 \\
\hline 6 & Lithuania & 3 & 4 & 4 & 4 & 0 & 0 & 0 \\
\hline 7 & Luxembourg & 2 & 6 & 29 & 0 & 0 & 0 & 0 \\
\hline 8 & Germany & 3 & 5 & 25 & 35 & 0 & 0 & 0 \\
\hline 9 & Poland & 3 & 3 & 7 & 4 & 0 & 0 & 0 \\
\hline
\end{tabular}

The study showed that the number of distinguished classes of objects at the first level of detail is similar in:

- Austria, the Czech Republic and Poland, which each has 3 object classes,

- Bulgaria, Lithuania, which each has 4 object classes.

In relation to the remaining countries, a large degree of diversity was noted in the manner of distinguishing classes of land use objects at individual levels of detail.

The results of the study on the number of classes of land use objects at individual levels of detail are presented in Table 2.

Table 2. The number of groups at each level of detail

\begin{tabular}{||c|c|c|c|c||}
\hline Detail levels & $\begin{array}{c}\text { The minimum } \\
\text { number } \\
\text { of classification } \\
\text { levels }\end{array}$ & $\begin{array}{c}\text { A country with } \\
\text { a minimum } \\
\text { number } \\
\text { of classification } \\
\text { levels }\end{array}$ & $\begin{array}{c}\text { The maximum } \\
\text { number } \\
\text { of classification } \\
\text { levels }\end{array}$ & $\begin{array}{c}\text { A country with } \\
\text { a maximum } \\
\text { number } \\
\text { of classification } \\
\text { levels }\end{array}$ \\
\hline \hline $1^{\text {st level }}$ & 1 & Spain & 11 & Estonia \\
\hline $2^{\text {nd }}$ level & 2 & Estonia & 29 & Luxembourg \\
\hline $3^{\text {rd }}$ level & 4 & Poland, Lithuania & 35 & Germany \\
\hline
\end{tabular}


The analyses show major differences in the degree of detail and the number of distinguished classes of objects.

Table 3. Percentage share of the number of object classes at individual levels of detail in relation to all distinguished land use classes

\begin{tabular}{||c|c|c|c|c|c|c|c||}
\hline $\begin{array}{c}\text { Ord. } \\
\text { no. }\end{array}$ & Country & $\begin{array}{c}\text { Number } \\
\text { of classes } \\
\text { at the } 1^{\text {st }} \\
\text { detail } \\
\text { level [\%] }\end{array}$ & $\begin{array}{c}\text { Number } \\
\text { of classes } \\
\text { at the } 2^{\text {nd }} \\
\text { detail } \\
\text { level [\%] }\end{array}$ & $\begin{array}{c}\text { Number } \\
\text { of classes } \\
\text { at the } \text { 3 }^{\text {rd }} \\
\text { detail } \\
\text { level [\%] }\end{array}$ & $\begin{array}{c}\text { Number } \\
\text { of classes } \\
\text { at the } 4^{\text {th }} \\
\text { detail } \\
\text { level [\%] }\end{array}$ & $\begin{array}{c}\text { Number } \\
\text { of classes } \\
\text { at the } 5^{\text {th }} \\
\text { detail } \\
\text { level [\%] }\end{array}$ & $\begin{array}{c}\text { Number } \\
\text { of classes } \\
\text { at the } 6^{\text {th }} \\
\text { detail } \\
\text { level [\%] }\end{array}$ \\
\hline \hline 1 & Austria & 38 & 52 & 0 & 0 & 0 & 0 \\
\hline 2 & Bulgaria & 57 & 0 & 0 & 0 & 0 & 0 \\
\hline 3 & the Czech Republic & 30 & 66 & 0 & 0 & 0 & 0 \\
\hline 4 & Estonia & 85 & 100 & 0 & 0 & 0 & 0 \\
\hline 5 & Spain & 50 & 100 & 0 & 0 & 0 & 0 \\
\hline 7 & Lithuania & 80 & 67 & 57 & 0 & 0 & 0 \\
\hline 8 & Luxembourg & 67 & 59 & 0 & 0 & 0 & 0 \\
\hline 9 & Poland & 50 & 50 & 33 & 0 & 0 & 0 \\
\hline
\end{tabular}

The results of the study on the percentage share of the number of distinguished classes of objects related to urban areas in relation to all the distinguished classes of land use objects (Tab. 3) are presented in Table 4.

Table 4. Percentage share of the number of distinguished classes of objects related to urban areas in relation to all the distinguished classes of land use objects

\begin{tabular}{|c|c|c|c|c||}
\hline Detail levels & $\begin{array}{c}\text { The minimum } \\
\text { percentage share } \\
\text { of the number } \\
\text { of object classes } \\
\text { related to urban } \\
\text { areas [\%] }\end{array}$ & $\begin{array}{c}\text { Country with } \\
\text { the minimum } \\
\text { percentage share } \\
\text { of the number } \\
\text { of object classes } \\
\text { related to urban } \\
\text { areas }\end{array}$ & $\begin{array}{c}\text { The maximum } \\
\text { percentage } \\
\text { share } \\
\text { of the number } \\
\text { of object } \\
\text { classes related } \\
\text { to urban areas } \\
{[\%]}\end{array}$ & $\begin{array}{c}\text { Country with } \\
\text { the maximum } \\
\text { percentage share } \\
\text { of the number } \\
\text { of object classes } \\
\text { related to urban } \\
\text { areas }\end{array}$ \\
\hline \hline $1^{\text {st level }}$ & 30 & the Czech Republic & 85 & Estonia \\
\hline $2^{\text {nd }}$ level & 50 & Poland & 100 & $\begin{array}{c}\text { Estonia } \\
\text { Spain }\end{array}$ \\
\hline $3^{\text {rd }}$ level & 33 & Poland & 85 & Germany \\
\hline
\end{tabular}


The study showed that there are two countries, Estonia and Spain, which have the same percentage share of the distinguished classes of objects related to urban areas in relation to all the distinguished classes of land use objects at the second level of detail, namely $100 \%$. In the case of the other countries, there is a great degree of diversity and those surveyed do not show similarities in the number of distinguished classes of objects related to urban areas in relation to all the distinguished classes of land use objects.

\section{Conclusions}

The conducted research permits the conclusion that the analyzed countries are characterized by a diversity of the scope of information on land use. The classification functioning in the examined European countries is not extensive.

The research carried out on documents made available by governmental institutions showed that the analyzed countries are characterized by a discrepancy in the number of separate levels of land use classification in urbanized areas. In addition, the research shows a discrepancy in the number of distinguished classes of objects registered at individual levels of detail and a discrepancy in the percentage share of the distinguished classes of objects related to urbanized areas in relation to all classes of objects related to the use of land in urbanized areas. The research problem presented in the article is extremely important due to the numerous initiatives aimed at broadening the knowledge of land use in various European countries. The research results presented in the article constitute the first stage of the analysis of the registration in cadastral land use systems in selected European countries.

\section{References}

[1] Permanent Committee on Cadastre in the European Union: Cadastral Information System, 2008.

[2] Permanent Committee on Cadastre in the European Union: Cadastral Information System, 2009.

[3] Bykov P.: Comparison of Russian and Finnish Planning Systems and Land Use Laws. Saimaa University of Applied Sciences Double Degree Programme Civil and Construction Engineering, 2012 [thesis].

[4] Hardy E.E., Anderson J.R.: A Land Use Classification System for Use with Remote-Sensor Data. LARS Symposia, Paper 2, 1973. https://docs.lib.purdue. edu/lars_symp/2/ [access: 20.10.2020].

[5] Lei G., Li A., Bian J., Zhang Z.: The roles of criteria, data and classification methods in designing land cover classification systems: evidence from existing land cover data sets. International Journal of Remote Sensing, vol. 41, issue 14, 2020, pp. 5062-5082. https://doi.org/10.1080/01431161.2020.1724349. 
[6] Di Gregorio A.: FAO Land Use Statistics: A Case Study for Three Countries Using Remote Sensing and GIS Technology. Consultancy Report, FAO Statistics Division, Rome 1995.

[7] Zhang X., Shi S., Lv Z.: Uncertainty Assessment in Multitemporal Land Use/Cover Mapping with Classification System Semantic Heterogeneity. Remote Sensing, vol. 11, issue 21, 2019, 2509. https://doi.org/10.3390/rs11212509.

[8] Zalewski M.: Pasożytki gruntowe. Przegląd Geodezyjny, nr 4, 2014, p. 28.

[9] Bundesgesetz vom 3. Juli 1968 über die Landesvermessung und den Grenzkataster (Vermessungsgesetz) [Federal Law of July 3, 1968 on Land Surveying and the Boundary Cadastre - Surveying Law] - Austria.

[10] Vyhláška ze dne 1. listopadu 2013 o katastru nemovitostí (katastrální vyhláška), č. 357/2013 Sb. [Decree of 1 November 2013 on the Real Estate Cadastre (Cadastral Decree), No. 357/2013 Coll.] - the Czech Republic.

[11] Kinnistusraamatuseadus, Vastu võetud 15.09.1993, RT I 1993, 65, 922 [Land Register Act, adopted on 15.09.1993, RT I 1993, 65, 922] - Estonia.

[12] Rozporzadzenie Ministra Rozwoju Regionalnego i Budownictwa z dnia 29 marca 2001 r. ws sprawie ewidencji gruntów ibudynków. Dz.U. 2001 nr 38, poz. 454 [Regulation of the Minister of Regional Development and Construction of 29 March 2001 on the land and buildings register. Journal of Laws of 2001, no. 38, item 454] Poland.

[13] Katastriüksuse sihtotstarvete liigid ja nende määramise kord, Vastu võetud 23.10.2008, RT I 2008, 46, 260 [Types of purposes of the cadastral unit and the procedure for determining them, adopted on 23.10.2008, RT I 2008, 46, 260] Estonia.

[14] Verordnung des Bundesministers für Wirtschaft, Familie und Jugend über die Angabe und Definition der Benützungsarten und Nutzungen im Grenzkataster, BGB1. II Nr. 116/2010 [Ordinance of the Federal Minister for Economic Affairs, Family and Youth on the indication and definition of the types of use and uses in the border cadastre, BGB1. II No. 116/2010] - Austria.

[15] Real Decreto Legislativo 2/2008, de 20 de junio, por el que se aprueba el texto refundido de la Ley de suelo [Royal Legislative Decree 2/2008 of 20 June, Approving the Revised Text of the Land Law Was Approved] - Spain.

[16] Zakon za ustroystvo na teritoriyata, v sila ot 31.03.2001 g. [Spatial development Act, in force from 31.03.2001] - Bulgaria.

[17] Lietuvos Respublikos nekilnojamojo turto kadastro ìstatymas $2000 \mathrm{~m}$. birželio 27 d., Nr. VIII-1764 [Law on Real Estate Cadastre of the Republic of Lithuania, 2000 June 27, No. VIII-1764] - Lithuania.

[18] Lietuvos Respublikos Žemès Ükio Ministro Isakymas dèl žemés fondo apskaitos taisykliu patvirtinimo, 2002 m. rugpjūčio 7 d., Nr. 302 [Order of the Minister of Agriculture of the Republic of Lithuania on Approval of Land Fund accounting rules, 2002, 7th of August, No. 302] - Lithuania. 